\title{
Evaluation Fungicides against Phytophthora nicotianae Causing Black Shank Disease in FCV Tobacco Both Under In vitro and In vivo
}

\author{
K. Jayalakshmi ${ }^{1 *}$, J. Raju ${ }^{1}$ and H. Ravindra ${ }^{2}$ \\ ${ }^{1}$ Department of Plant Pathology, AINRP (Tobacco), ZAHRS, University of Agricultural and \\ Horticultural Sciences, Shivamogga, Karnataka 577204, India \\ ${ }^{2}$ Department of Plant Pathology, Plant Quarantine Station, DPPQS, Mangalore, Karnataka, India \\ *Corresponding author
}

\section{A B S T R A C T}

Keywords

Phytophthora nicotiane, Black shank, FCV

tobacco,

Fungicides, Management.

Article Info

Accepted:

26 June 2017

Available Online:

10 July 2017
Black shank, Phytophthora parasitica var. nicotianae is a major disease of tobacco results in considerable loss of the crop. An investigation was carried out to screen the different fungicides to inhibit the growth of black shank pathogen. Among eight fungicides tested at different concentrations, 0.1 per cent of Trifloxystrobin + Tebuconazole, Fenamidone + Mancozeb and Metalaxyl + Mancozeb were showed cent per cent inhibition and found effective over all the tested fungicides. Management study under field conditions was carried out during kharif 2016, revealed that the treatment with Fenamidone + Mancozeb and Cymoxanil + Mancozeb found effective in reducing the disease incidence of $19.05 \%$ and $23.02 \%$ with highest green leaf yield (10596.71 and $9920.63 \mathrm{~kg} / \mathrm{ha}$ ), cured leaf yield (1246.67 and $1167.13 \mathrm{~kg} / \mathrm{ha})$ and top grade equivalent (872.67 and $700.28 \mathrm{~kg} / \mathrm{ha}$ ) followed by Azoxystrobin and Metalaxyl Mz over untreated check. All tested fungicides were drastically reduced disease the incidence and showed a tendency to increase tobacco yield over the untreated control.

\section{Introduction}

Among the commercial crops grown in India, tobacco (Nicotiana tabacum) occupies an important place not only as a valuable foreign exchange earner but also as an employment as a generating crop. Tobacco like any other crop is susceptible to several diseases in which black shank is one of the serious problem of Flue Cured Virginia tobacco in Karnataka light soil. Black shank of tobacco, caused by the hemibiotrophic oomycete Phytophthora parasitica f. sp. nicotianae (Breda de Haan) Tucker is among the most destructive and widespread of all tobacco-cultivated area (Prinsloo, 1994). The Pathogen damage the pith (the water transport system of the plant) of a plant resulted wilting, stunting, yellowing leaves and finally plant dies (Lucas, 1975). Black shank first appeared in the United States in 1915 and was first reported in North Carolina in Forsyth County in 1931. The fungus can survive in the soil for many years, even in the absence of tobacco (Shew and Lucas, 1991; Jones and Shew, 1995; Shamrao and Hundekar, 2009). The disease can be managed in many ways. For effective black shank control, growers use 
a combination of crop rotation, cultivar resistance and fungicide applications (Melton 1998). Application of effective fungicides continues to be a viable component in developing integrated disease management programme. In this context the present investigation was carried out on management of black shank disease by using different fungicides under natural field condition.

\section{Materials and Methods}

In vitro evaluation of fungicides against $P$. nicotiane

The study was conducted at Plant Pathology department, University of Agricultural and Horticultural Scinces, Shivamogga during 2016. The efficacy of two systemic and six combi fungicides viz., Fosetyle Al (Allite), Azoxystrobin 23EC (Amistar), Zineb 68\% + Hexaconazole 4\% WP (Avtar), Cymaxonil $8 \%+$ Mancozeb $65 \%$ (Curzate), Famoxadone 16.6\%+ Cymoxanil 22.1 \% (Equation Pro), Fenamidone 10\% + Mancozeb 50 WG (Sectin 60 WG), Trifloxystrobin 25\% + Tebuconazole $50 \%$ WG (Nativo) and Metalaxyl 8\% + Mancozeb 64\% WP (Rodomil gold) were tested at 0.1, 0.15 and 0.2 per cent concentration against $P$. nicotiane for radial growth inhibition on the potato dextrose agar media using poisoned food technique under in vitro condition.

The quantity of fungicides was calculated for $100 \mathrm{ml}$ medium separately. The requisite quantity of fungicides was added to each flask at $45 \mathrm{C}$. the fungicides were thouroghlly mixed before solidification and poured into sterilized Petri plates. The mycelium of $5 \mathrm{~mm}$ diamere of five days old culture was cut with the help of sterile corkborer. Each disc was transferred aseptically to the centre of each Petri plate, already poured with poisoned medium. The PDA plates without fungicides were also inoculated and maintained as control. The plates were incubated for 6 days The observations on colony growth was recorded until Petri plate in control treatment was fully covered with mycelia growth and calculated the per cent inhibition by using the formula given by Vincent (1947).

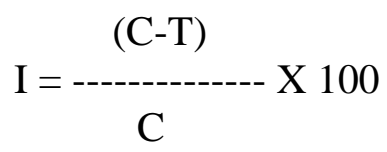

Where,

$\mathrm{I}=$ Per cent inhibition

$\mathrm{C}=$ Radial growth in control

$\mathrm{T}=$ Radial growth in treatment (fungicide)

Evaluation of fungicides against black shank of FCV tobacco under field condition during kharif 2016

The experiment was carried out during kharif 2016 at Zonal Agricultural Research Station, Navile, Shimoga, Karnataka. The soil type was loamy soil and had the black shank pathogen (Phytophthora nicotiane) population to an extent of $6 \times 10^{6} \mathrm{cfu} / \mathrm{g}$ of soil. The experimental plot size was 5.4 x $4.0 \mathrm{~m}$ with seven treatments of three replication and laid out in Randomized Complete Block Design.

The variety, Sahaydri was used and plots was drenched (50ml/plant) with different fungicides viz., Fosetyl Al @ 0.1\%, Zineb $68 \%$ + Hexaconazol 4\% WP @ 0.2\%, Trifloxystrobin 25\% and Tebuconazole 50 \%WG@0.1\%, Cymoxanil 8\% + Mancozeb 64\% WP @ 0.2\%, Famoxadone 16.6\%+ Cymoxanil 22.1\%@0.1\%, Azoxystrobin 23 EC @ 0.1\%, Fenamidone 10\% + Mancozeb 50 WG@0.2\%, Metalaxyl 8\% + Mancozeb 64\% WP @ 0.2\% (RC) and one check. These plots were watered by surface irrigation at regular intervals (6 to 8 days) throughout the season and stopped 15 days before harvesting. An observation on disease incidence was 
scored using 0-5 scale, and yield parameters viz., green leaf weight, cured leaf weight and total grade equivalent (TGE) were recorded.

\section{Statistical Analysis}

The experimental data collected were analyzed statistically for its significance of difference by the normal statistical procedure adopted for completely randomized design and randomized block design. Data from the percent inhibition, percent disease incidence and yield were analyzed by ANOVA. Percent data were transformed arcsine where necessary. Differences within the means were compared by using Fisher's LSD (Least Significant Difference) test (Steel et al., 1997).

\section{Results and Discussion}

\section{In vitro evaluation of fungicides against Phytopthora nicotiane}

It was revealed from the results (Table 1) that all systemic and combi fungicides at different concentrations significantly inhibit the mycelial growth of $P$. nicotiane. The fungicides, Fenamidone + Mancozeb, Cymoxanil + Mancozeb, and Metalaxyl + Mancozeb at $0.1,0.15$ and 0.2 per cent concentrations showed cent percent inhibition and remaining were showed more than 50 per cent mycelial inhibition at all the tested concentration. However, the Fenamidone + Mancozeb, Cymoxanil + Mancozeb, and Metalaxyl + Mancozeb at all tested concentration caused 100 percent reduction of mycelail growth followed by Azoxystrobin $(79.56 \%)$, Trifloxystrobin + Tebuconazole $(79.11 \%)$, Famoxadone + Cymoxanil $(78.67 \%)$ Zineb + Hexaconazole (73.33\%), and Fosetyl $\mathrm{Al}(70.22 \%)$ at 0.2 percent concentration respectively. It was observed from the study that amongst tested fungicides combi fungicides found significantly superior in showing cent percent inhibition of the mycelial growth of the P.nicotiane. Jahagirdar (1998) reported the fungicidal nature of Akomin, a plant tonic generally being recommended for plantation crops. The laboratory evaluation of Ridomil against $P$. parasitica var. nicotianae revealed significant reduction in growth and sporulation of fungus at $0.1,0.2,0.3$ and 0.4 per cent concentration. Sastry (1982) reported Bordeaux mixture (1\%), Blitox and Metalaxyl which were found effective in inhibiting the growth and sporangial formation of $P$. capsici and $P$. meadii. Similar reports in in vitro screening were reported by Ramachandran and Sarma (1990), Ramachandran et al., (1990). The present investigation results are also in line with the findings of Subramanyam (1993), Jahagirdar (1998) and Veena and Sarma (2000). Studies on metalaxyl as effective fungicide agent $P$. parasitica var. nicotianae causing black shank of tobacco was reported by Vasilakakis et al., (1979).

\section{Evaluation of fungicides against black shank of FCV tobacco under field condition during kharif 2016}

Eight different fungicides (two systemic and six combi) present in the local market were tested for their antifungal potential against $P$. nicotiane under natural field conditions in curative manner. The incidence of black shank as well as the green leaf yield cured leaf yield and total grade equivalent (TGE) varied with the application of different new molecules of fungicides in field condition. Soil application of fungicides during and after planting, reduced the disease incidence and increased the yield parameters. The results from table 2 reveal that, all the tested fungicides were significantly effective in reducing the disease incidence. Maximum reduction of the disease incidence of $19.05 \%$ and $23.02 \%$ were recorded application of Fenamidone + Mancozeb at $0.3 \%$ and 
Cymoxanil + Mancozeb at $0.2 \%$ as compared untreated control (76.19\%) respectively. Further $0.1 \%$ of Azoxystrobin (25.40\%) $0.1 \%$ of Metalaxyl + Mancozeb (30.95\%) and Fosetyl Al (34.92\%) found effective in reducing the disease incidence followed by Least percent disease reduction was recorded in Famoxadone + Cymoxanil at $0.1 \%$ and Zineb + Hexaconazole of 33.34 and $34.48 \%$ over control. Correspondingly, Fenamidone + Mancozeb and Cymoxanil + Mancozeb applied plots yielded higher green leaf of 10596.71 and $9920.63 \mathrm{~kg} / \mathrm{ha}$, cured leaf of 1246.67 and $1167.13 \mathrm{~kg} / \mathrm{ha}$ and top grade equivalent of 872.67 and $700.28 \mathrm{~kg} / \mathrm{ha}$ respectively over untreated check (5291.01, 622.47 and $497.98 \mathrm{~kg} / \mathrm{ha}$ ). Therefore the combi fungicide Fenamidone + Mancozeb was found most effective in reducing the black shank disease in FCV tobacco and thereby increasing the leaf yield.

Table.1 Evaluation of fungicides against Phytopthora parasitica var. nicotiane under in vitro

\begin{tabular}{|c|c|c|c|c|}
\hline \multirow{3}{*}{ Fungicides } & \multirow{2}{*}{\multicolumn{3}{|c|}{$\begin{array}{l}\text { Per cent Inhibition } \\
\text { Concentration }(\%)\end{array}$}} & \multirow{3}{*}{ Mean } \\
\hline & & & & \\
\hline & 0.1 & 0.15 & 0.2 & \\
\hline Fosetyl Al & $\begin{array}{c}54.22 \\
(47.45)\end{array}$ & $\begin{array}{c}64.00 \\
(53.16)\end{array}$ & $\begin{array}{c}70.22 \\
(56.98)\end{array}$ & 62.81 \\
\hline $\begin{array}{l}\text { Zineb } 68 \% \\
\text { Hexaconazole } 4 \% \text { WP }\end{array}$ & $\begin{array}{c}66.67 \\
(54.76)\end{array}$ & $\begin{array}{l}69.33 \\
(56.40)\end{array}$ & $\begin{array}{c}73.33 \\
(58.94)\end{array}$ & 69.78 \\
\hline $\begin{array}{lr}\text { Cymoxanil } 8 \% \\
\text { Mancozeb 64\% WP }\end{array}$ & $\begin{array}{l}100.00 \\
(90.05)\end{array}$ & $\begin{array}{l}100.00 \\
(90.05)\end{array}$ & $\begin{array}{l}100.00 \\
(90.05)\end{array}$ & 100.00 \\
\hline $\begin{array}{l}\text { Trifloxystrobin } 25 \% \\
+ \text { Tebuconazole } 50 \% \mathrm{WG}\end{array}$ & $\begin{array}{c}60.89 \\
(51.32)\end{array}$ & $\begin{array}{c}68.89 \\
(56.13)\end{array}$ & $\begin{array}{c}79.11 \\
(62.95)\end{array}$ & 69.63 \\
\hline $\begin{array}{l}\text { Famoxadone } \\
\text { Cymoxanil } 22.1 \%\end{array}$ & $\begin{array}{l}59.11 \\
(50.28)\end{array}$ & $\begin{array}{c}62.22 \\
(52.10)\end{array}$ & $\begin{array}{c}78.67 \\
(62.61)\end{array}$ & 66.67 \\
\hline Azoxystrobin 23 EC & $\begin{array}{c}54.67 \\
(47.70)\end{array}$ & $\begin{array}{c}60.00 \\
(50.79)\end{array}$ & $\begin{array}{l}79.56 \\
(63.31)\end{array}$ & 64.74 \\
\hline $\begin{array}{l}\text { Fenamidone } 10 \% \\
\text { Mancozeb } 50 \mathrm{WG}\end{array}$ & $\begin{array}{l}100.00 \\
(90.05)\end{array}$ & $\begin{array}{l}100.00 \\
(90.05)\end{array}$ & $\begin{array}{l}100.00 \\
(90.05)\end{array}$ & 100.00 \\
\hline $\begin{array}{l}\text { Metalaxyl 8\% + Mancozeb } \\
64 \% \text { WP }\end{array}$ & $\begin{array}{l}100.00 \\
(90.05)\end{array}$ & $\begin{array}{l}100.00 \\
(90.05)\end{array}$ & $\begin{array}{l}100.00 \\
(90.05)\end{array}$ & 100.00 \\
\hline & $\begin{array}{l}\text { Fungicides } \\
\text { (F) }\end{array}$ & $\begin{array}{l}\text { Concentration } \\
\text { (C) }\end{array}$ & $\mathrm{I}(\mathrm{F} \times \mathrm{C})$ & \\
\hline S.Em \pm & 1.66 & 1.02 & 2.88 & \\
\hline $\mathrm{CD}$ at $1 \%$ & 4.46 & 2.73 & 7.73 & \\
\hline
\end{tabular}

*Figures in parenthesis are Arc sine transformed values 
Table.2 Evaluation of fungicides against tobacco black shank disease under Field condition during kharif, 2016

\begin{tabular}{|c|c|c|c|c|c|c|}
\hline \multirow[b]{2}{*}{ Treatments } & \multirow{2}{*}{$\begin{array}{c}\text { Concentration } \\
(\%)\end{array}$} & \multirow[b]{2}{*}{$\begin{array}{l}\% \text { Disease } \\
\text { incidence }\end{array}$} & \multirow{2}{*}{$\begin{array}{c}\text { Percent } \\
\text { disease } \\
\text { reduction } \\
\text { over } \\
\text { control }\end{array}$} & \multicolumn{3}{|c|}{ Yield (Kg/ha) } \\
\hline & & & & Green leaf & Cured leaf & TGE \\
\hline Fosetyl Al & 0.1 & $34.92(36.23)$ & 54.17 & 6188.71 & 726.22 & 544.66 \\
\hline $\begin{array}{l}\text { Zineb } 68 \% \quad+ \\
\text { Hexaconazole } 4 \% \text { WP }\end{array}$ & 0.2 & $49.92(36.24)$ & 34.48 & 7863.02 & 925.06 & 647.54 \\
\hline $\begin{array}{l}\text { Cymoxanil } 8 \% \\
\text { Mancozeb 64\% WP }\end{array}$ & 0.2 & $23.02(28.64)$ & 69.79 & 9920.63 & 1167.13 & 700.28 \\
\hline $\begin{array}{l}\text { Trifloxystrobin } 25 \% \\
\text { and Tebuconazole } 50 \\
\% \mathrm{WG}\end{array}$ & 0.1 & $39.68(39.06)$ & 47.92 & 6804.82 & 800.57 & 640.45 \\
\hline $\begin{array}{l}\text { Famoxadone } 16.6 \%+ \\
\text { Cymoxanil } 22.1 \%\end{array}$ & 0.1 & $50.79(45.48)$ & 33.34 & 7848.32 & 923.33 & 738.67 \\
\hline Azoxystrobin $23 \mathrm{EC}$ & 0.1 & $25.40(30.21)$ & 66.66 & 9553.20 & 1123.91 & 674.34 \\
\hline $\begin{array}{l}\text { Fenamidone } 10 \%+ \\
\text { Mancozeb 50 WG }\end{array}$ & 0.2 & $19.05(25.80)$ & 75.00 & 10596.71 & 1246.67 & 872.67 \\
\hline $\begin{array}{lrr}\text { Metalaxyl } & 8 \% & + \\
\text { Mancozeb } & 64 \% & \text { WP } \\
(\mathrm{RC}) & & \\
\end{array}$ & 0.2 & $30.95(33.74)$ & 59.38 & 8377.43 & 985.58 & 689.91 \\
\hline Untreated Control & - & $76.19(60.84)$ & 0.00 & 5291.01 & 622.47 & 497.98 \\
\hline S.Em \pm & & 1.32 & - & 244.48 & 28.76 & 20.27 \\
\hline $\mathrm{CD}$ at $5 \%$ & & 3.97 & - & 732.94 & 86.23 & 60.77 \\
\hline
\end{tabular}

*Figures in parenthesis are Arc sine transformed values

The combi fungicides is very effective in managing black shank proved by (Karegowda 2014) as the application of Fenamidone + Mancozeb consistently retarded black shank development and increased the yield when used in combination with Mancozeb due to the reason of that being contact fungicide Mancozeb does not persist long on the stem (Suryanaraya and Rajarao 1988, Amrinder et al., 2009 and Ghazanfar et al., 2010) and plots that applied with longer intervals were unprotected. The above statement is also in confirmation with our findings.

The effectiveness of Fenamidone + Mancozeb is attributed to its ability to inhibit the persistence of inoculum and production of chlamydospores and oospores on the treated portions than the Metalaxyl Mz treatments. The results of Karegowda (2014) and Dam (2015) are also in line with the present studies, as they reported that application of Fenamidone + Mancozeb highly effective for the control of black shank with. CTRI, Rajmundry tried various fungicides against Phytophthora black shank disease and found Fenamidone + Mancozeb as the best for reduction in incidence on tobacco stem and it is a promising alternative to Metalaxyl Mz. The systemic fungicide metalaxyl (Ridomil, matco 8-64), Fosetyl Al (Aliette) both as foliar spray and soil drench were found effective against Phytophthora capsici in field conditions (Ramachandran and Sarma, 
1985a). Similarly Raju et al., in 2016 showed that, the Fenamidone + Mancozeb and Azoxystrobin, treated the plots of tobacco reduced the incidence of black shank on stem and increased green leaf yield, cure leaf yield and total grade equivalent relative to control plots. The new molecules of fungicides is very effective in managing black shank proved by Karegowda, 2015 as the application of Fenamidone + Mancozeb consistently retarded late disease development and increased the yield parameters and the plots that applied with longer intervals were unprotected. The above statement is also in confirmation with our finding.

In conclusion, Chemical control remains the most important control measure against black shank. The control strategy is primarily preventive but in case the pathogen infects the crop, the epidemic must be stopped by using more powerful formulations. All the recommended fungicides against Phytophthora parasitica f. sp. nicotianae and were found compatible effective at their respective recommended doses. Among them, combi product Fenamidone 10\% + Mancozeb $50 \mathrm{WG}$ ( 0.1 percent) significantly reduced the black shank disease incidence in the field and achieving the higher green leaf yield, cured leaf yield and total grade equivalent over other treatments.

\section{References}

Amrinder Kaur, K.S., Vermaand S.K. and Thind. 2009. Evaluation of fungicides against citrus foot rot (Phytophthora nicotianae var. parasitica). Pl. dis. Res. 24(1):19-22.

Dam, S. K. 2015. Research achievements, Proceedings of Institute Research Committee Meetings. ICAR-Central Tobacco Research Institute, Rajahmundry. 18-19.

Erwin, D.C., and Ribeiro, O.K. 1996.
Phytophthora Diseases Worldwide. American Phytopathological Society Press, St. Paul, MN 1: 225-300.

Ghazanfar, M.U., S.T. Sahi, W. Wakil and Z. Iqbal., 2010. Evaluation of various fungicides for the management of late blight of potato (Phytophthora infestans). Pak. J. Phytopathol. 22(2): 83-88.

Jones, K. J., and Shew. H. D., 1995. Early season root production and zoospore infection of cultivars of flue-cured tobacco that differ in level of partial resistance to Phytophthora parasitica var. nicotianae. Plant Soil 172:55-61.

Karegowda C. 2014. Research achievements, Proceedings of Institute Research Committee Meetings. ICAR-Central Tobacco Research Institute, Rajahmundry 20-21.

Karegowda C., 2015. Narayanaswamy H., Raju J., Sharabasappa H G., Ganesh Naik R. and Murali R. Integrated management of black shank disease of FCV tobacco in field and its effect on leaf yield and quality parameters. In $3^{\text {rd }}$ International Symposium on Phytophthora: Taxonomy, Genomics, Pathogenicty, Resistance and Disease management. 9-12 ${ }^{\text {th }}$ Sep. p 51.

Lucas, G. B., 1975. Diseases of Tobacco. 3rd ed. Biological Consulting Associates, Raleigh, NC. 3:125-129.

Melton T. A. 1998. Disease Management. Flue-Cured Tobacco Information, North Carolina Cooperative Extension Service, North Carolina State University, College of Agriculture and Life Science, pp. 92-112.

Prinsloo G.C. 1994. Black shank of tobacco in the Republic of South Africa. (Abstr.) p. 89. In: Coresta Congress 1994, Harare, Zimbabwe.

Raju, J, Ravindra, H., Mohan Kumar, S and Jayalakshmi, K., 2016. Efficacy of new 
molecules of fungicides against Black shank of tobacco under field condition. In $6^{\text {th }}$ International Conference on Plant Pathogens and people, by, IPS, ICAR, New Delhi 23-2 $7^{\text {th }}$ February. p 405.

Reddy, T.G.N. and Nagarajan, K., 1980, Evaluation of germplasm and chemical control of Phytophthora parasitica var. nicotianae on tobacco. Proc. Workshop on Phytophthora Diseases of Tropical Cultivated Plants 19-23, September, pp.100- 185.

Shamarao Jahagirdar and Hundekar, A. R., 2009. Major diseases of tobacco and their management in Karnataka- a review. Agric. Rev., 30(3): 206-212.

Shew, H.D. 1987. Effect of host resistance on spread of Phytophthora parasitica var. nicotianae and the subsequent development of tobacco black shank under field conditions. Phytopathology 77:1090-1093.

Shew, H.D., and Lucas. G.B., 1991. Compendium of Tobacco Diseases. American Phytopathological Society Press, St. Paul, MN. 1: 92-115.

Suryanarayana V. and Ch. Rajarao, D., 1988. Indian tobacco literature. Central Tobacco Research Institute, 1:26-30.

Vasilakakis, C.H.O., Hadzistavros. C.S. and Sterguinopolus, G.N., 1979, the use of systemic fungicides in soil application for the control of Phytophthora parasitica var. nicotianae in tobacco field in Greece-a preliminary report. Coresta Phytopath. Agron. Study Group Rep., pp.201-207.

\section{How to cite this article:}

Jayalakshmi, K., J. Raju and Ravindra, H. 2017. Evaluation Fungicides against Phytophthora nicotianae Causing Black Shank Disease in FCV Tobacco Both Under In vitro and In vivo. Int.J.Curr.Microbiol.App.Sci. 6(7): 2440-2446. doi: https://doi.org/10.20546/ijcmas.2017.607.346 